Geohydrology and

Water Utilization in the

Willcox Basin, Graham

and Cochise Counties

Arizona

GEOLOGICAL SURVEY WATER-SUPPLY PAPER 1859-F

Prepared in cooperation with the Arizona State Land Department

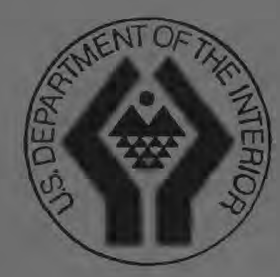




\section{Geohydrology and}

\section{Water Utilization in the}

\section{Willcox Basin, Graham}

\section{and Cochise Counties}

\section{Arizona}

By S. G. BROWN and H. H. SCHUMANN

CONTRIBUTIONS TO THE HYDROLOGY OF THE UNITED STATES

GEOLOGICAL SURVEY WATER-SUPPLY PAPER 1859-F

Prepared in cooperation with the Arizona State Land Department
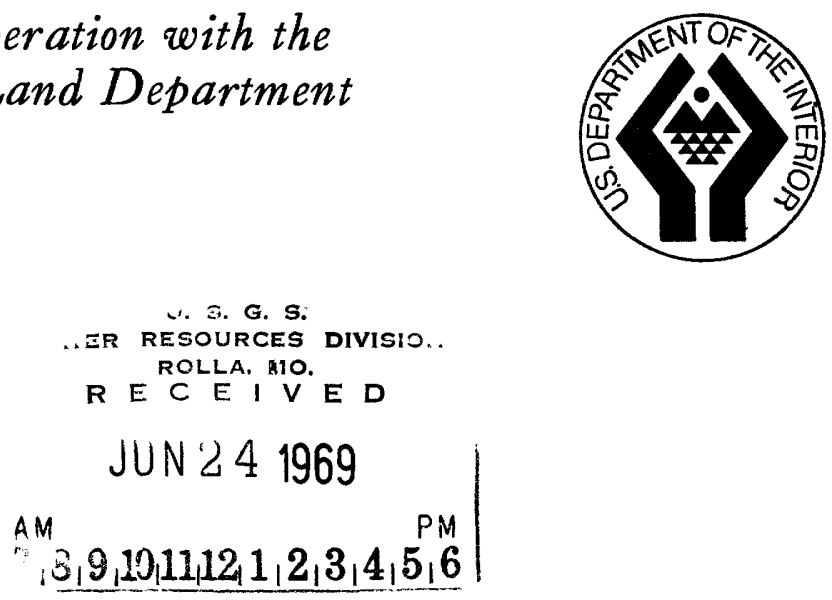


\section{UNITED STATES DEPARTMENT OF THE INTERIOR}

STEWART L. UDALL, Secretary

\section{GEOLOGICAL SURVEY}

William T. Pecora, Director 


\section{CONTENTS}

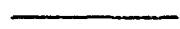

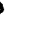




\section{ILLUSTRATIONS}

[Plates 1-3 are in pocket]

Plate 1. Geologic map and sections.

2. Map showing configuration of piezometric surface and generalized direction of ground-water movement.

3. Maps showing changes in ground-water levels.

Fraure 1. Map showing area of report.

2. Sketch showing well-numbering system in Arizona........

3-7. Graphs showing:

3. Accumulated deviation from the 1899-1957 average annual precipitation at Willeox..................

4. Specific capacities of wells in the Stewart and

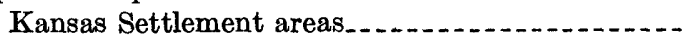

5. Estimated pumpage for irrigation in the three main

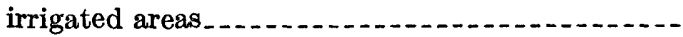

6. Cumulative pumpage in the Stewart area and water levels in well (D-13-24) 16bbb.

7. Cumulative change in water levels in observation wells

\section{TABLES}

TABLE 1. Summary of climatological data in the Willcox basin

2. Columnar section, stratigraphic table, and water-bearing characteristics of rock units in the Willcox basin....... 


\title{
GEOHYDROLOGY AND WATER UTILIZATION IN THE WILLCOX BASIN, GRAHAM AND COGHISE COUNTIES ARIZONA
}

\author{
By S. G. Brown and H. H. Schumann
}

\begin{abstract}
The Willcox basin is an area of interior drainage in the northern part of Sulphur Springs Valley, Cochise and Graham Counties, Ariz. The basin comprises about 1,500 square miles, of which the valley floor occupies about 950 square miles.

The basin probably formed during middle and late Tertiary time, when the area was subjected to large-scale faulting accompanied by the uplift of the mountain ranges that presently border it. During and after faulting, large quantities of alluvium were deposited in the closed basin.

The rocks in the basin are divided into two bread groups-the rocks of the mountain blocks, of Precambrian through Tertiary age, and the rocks of the basin, of Tertiary and Quaternary age. The mountain blocks consist of igneous, metamorphic, and sedimentary rocks; the water-bearing characteristics of these rocks depend primarily on their degree of weathering and fracturing. Even in areas where these rocks are fractured and jointed, only small amounts of water have been developed. The rocks of the basin consist of moderately consolidated alluvium, poorly consolidated alluvium, and unconsolidated alluvium. The water-bearing characteristics of the moderately and poorly consolidated alluvium are not well known. The unconsolidated alluvium underlies most of the valley floor and consists of two facies, stream deposits and lake beds associated with the old playa. The lenticular sand and gravel layers interbedded in silt- and clay-size material of the unconsolidated alluvium constitute the principal aquifer in the basin. The other aquifers, which yield less water, consist of beds of poorly to moderately consolidated sand- and gravel-size material; these beds occur in both the poorly consolidated and moderately consolidated alluvium.

In the Stewart area the median specific capacity of wells per 100 feet of saturated unconsolidated alluvium was 20 gallons per minute, and in the Kansas Settlement area the specific capacity of wells penetrating the poorly and moderately consolidated alluvium, undifferentiated, was only 7.4 gallons per minute per 100 feet of saturated material penetrated. The aquifer in the Kansas Settlement area is much less permeable but more homogeneous than the aquifer
\end{abstract}


in the Stewart area. The coefficient of transmissibility of the aquifers, which was estimated from the specific-capacity data, ranged from 58,000 to 160,000 gal. lons per day per foot.

Prior to extensive ground-water pumpage, the ground-water system probably was in equilibrium, with discharge equaling recharge. At that time, ground water moved toward the playa, where it was discharged by transpiration and evaporation. The estimate of the evapotranspiration in the playa area before large-scale development was about 75,000 acre-feet per year. On the basis of estimates of coefficients of transmissibility of the aquifer and on the basis of the water-table configuration, underflow toward the playa was computed to be about 54,000 acre-feet per year.

By 1963, large-scale pumping had caused marked changes in the shape of the piezometric surface; large cones of depression had developed, and ground-water movement was toward the centers of pumping. The cones of depression caused by large-scale pumping have since expanded, and water-level declines have been measured in the recharge areas along the mountain fronts.

Ground water has been used for irrigation since 1910. In 1928, about 4,000 acre-feet of ground water was pumped, and by 1963180,000 acre-feet per year was being pumped. An estimated 1,860,000 acre-feet of water has been pumped for irrigation in the Willcox basin through $1963 ; 680,000$ acre-feet from the Stewart area, 990,000 acre-feet from the Kansas Settlement area, and 190,000 acre-feet from the Pearce-Cochise area. In the Sierra Bonita Ranch area and the north playa area, ground-water withdrawal for irrigation through 1963 was small. From the spring of 1952 to the spring of 1964 water-level declines resulting from the withdrawal of ground water averaged about 29 feet in the Stewart area, about 19 feet in the Pearce-Cochise area, and about 74 feet in the Kansas Settlement area. Water-level declines for 1962-63 exceeded 10 feet per year in some wells in the more heavily pumped Kansas Settlement area and 7 feet per year in the Stewart area.

\section{INTRODUCTION}

The increasing use of ground water for irrigation and domestic and municipal uses has caused concern about the adequacy of the groundwater supplies in the Willcox basin (fig. 1). In July 1959 the U.S. Geological Survey began a study of the geohydrology of the Willcox basin as a part of the overall investigation of the water resources of the State in cooperation with the Arizona State Land Department, Obed M. Lassen, Commissioner.

The data used in this report were collected mainly from 1945 to 1960. Most of the well data-drillers' logs, reported well yields, and drawdowns-were obtained from well-registration forms of the Arizona State Land Department. Water-level measurements have been made by personnel of the U.S. Geological Survey since 1946.

The purpose of the investigation was to determine the occurrence, movement, availability, and chemical quality of the ground water in the basin. Special emphasis was placed on the effects of increased development of ground water for irrigation after 1953. 


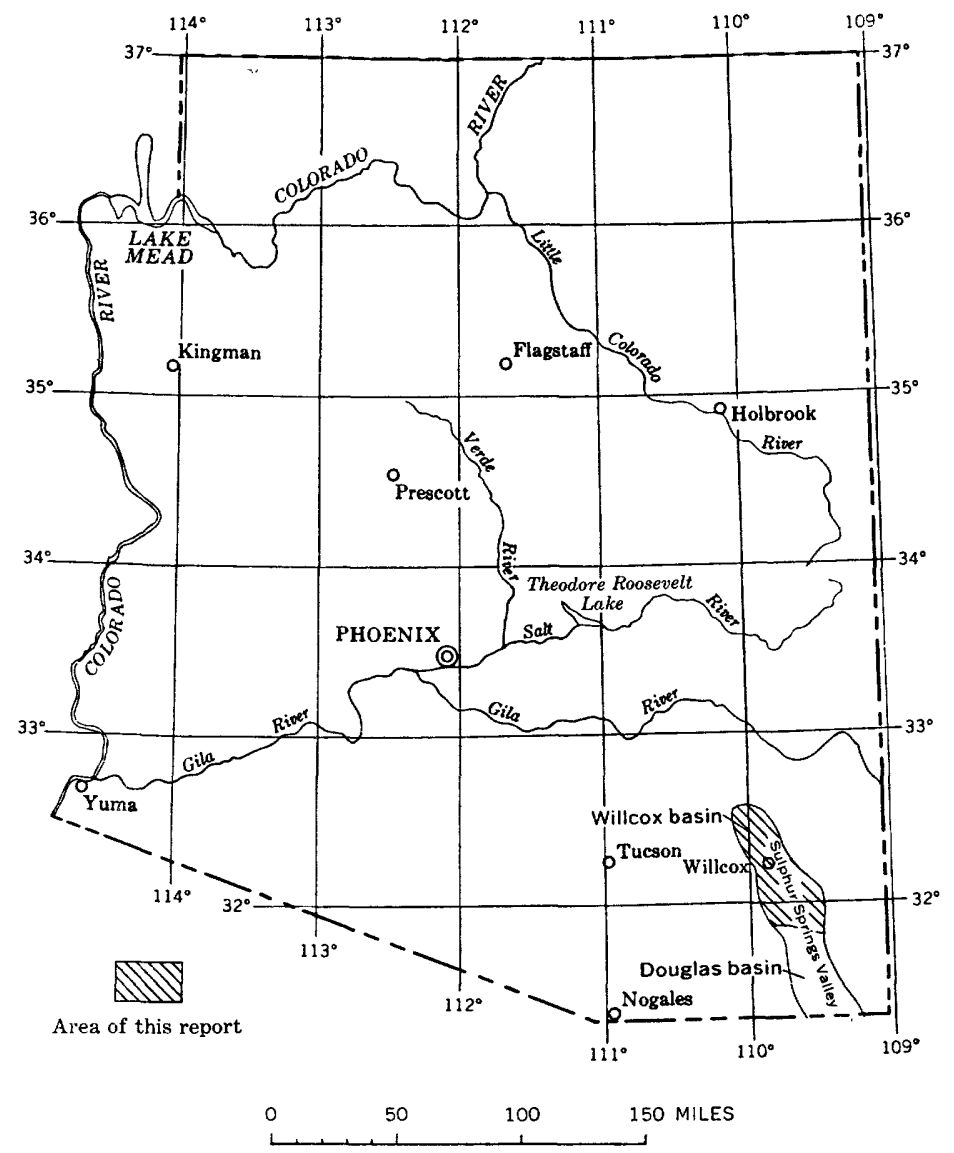

Figure 1.-Area of report.

Previous investigations of the ground-water resources in the Willcox basin were made by Meinzer and Kelton (1913) and Jones and Cushman (1947). Most of the basic data used in this report were published in Arizona State Land Department Water-Resources Report 14 (Brown and others, 1963). A report on the chemical quality of the ground water in the basin has been published as Hydrologic Investigations Atlas HA-214 (Kister and others, 1966).

\section{WELL-NUMBERING SYSTEM}

The well numbers used by the U.S. Geological Survey in Arizona are in accordance with the Bureau of Land Management's system of land subdivision. The land survey in Arizona is based on the Gila and Salt River meridian and base line, which divide the State into four quadrants (fig. 2). These quadrants are designated counterclockwise 
F4 CONTRIBUTIONS TO THE HYDROLOGY OF THE UNITED STATES

B

A
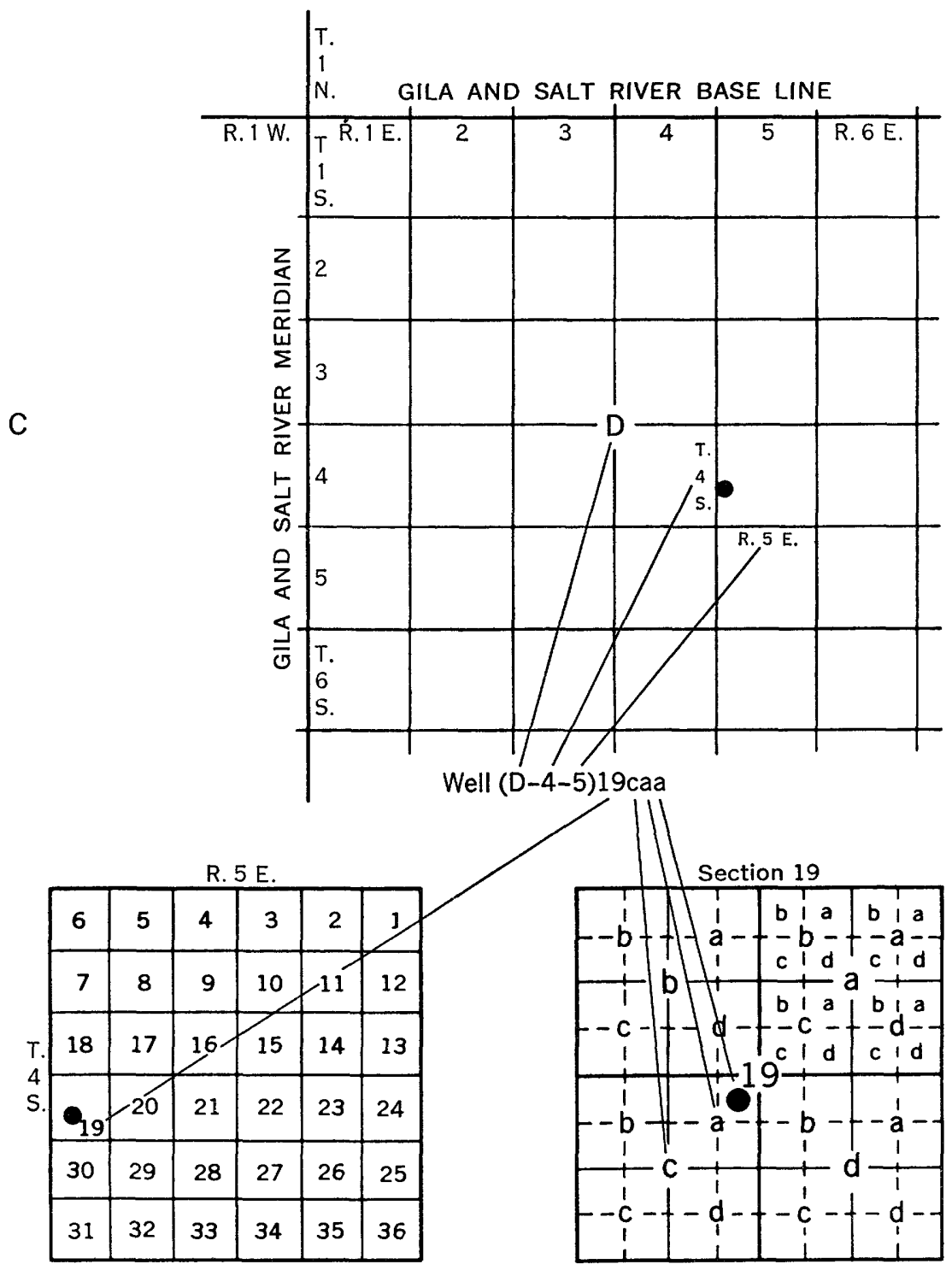

Fiqure 2.-Well-numbering system in Arizona. 
by the capital letters A, B, C, and D. All land north and east of the point of origin is in A quadrant, that north and west in B quadrant, that south and west in C quadrant, and that south and east in D quadrant. The first digit of a well number indicates the township, the second the range, and the third the section in which the well is situated. The lowercase letters $a, b, c$, and $d$ after the section number indicate the well location within the section. The first letter denotes a particular 160-acre tract, the second the 40-acre tract, and the third the 10-acre tract. These letters are also assigned in a counterclockwise direction, beginning in the northeast quarter. If the location is known within the 10-acre tract, three lowercase letters are added to the well number. In the following example, well number (D-4-5)19caa designates the well in the $\mathrm{NE}_{1 / 4} \mathrm{NE}_{1 / 4} \mathrm{SW}_{1 / 4}$ sec. $19, \mathrm{~T}$. 4 S., R. $5 \mathrm{E}$. Where there is more than one well within a 10 -acre tract, consecutive numbers beginning with 1 are added as suffixes.

\section{ACKNOWLEDGMENTS}

Well owners and operators in the area have been cooperative in furnishing information. Much supplemental information was obtained from pump companies and well drillers operating in the Willcox area. Mr. C. G. Page, County Agricultural Agent, Willcox, supplied estimates of irrigated acreage that were especially useful in computing irrigation pumpage. Mr. S. F. Turner, consulting engineer, Phoenix, Ariz., and the mayor and council of the city of Willcox granted access to data collected by Mr. Turner during an investigation made for the city. Mr. Gene Anderson and Mr. S. B. Evans of the consulting firm of Gene Anderson, Civil Engineers, Tucson, Ariz., allowed the use of data collected by them during a water-supply investigation for a land development near Ash Creek School. Mr. L. C. Halpenny, consulting engineer of the Water Development Corp., and Mr. W. B. Loving, manager of the Arizona Electric Power Cooperative, allowed access to data collected during an investigation for water to supply a thermoelectric plant near Cochise. The El Paso Natural Gas Co. contributed data obtained during the drilling of a new well to supply the compressor station east of the Kansas Settlement area and southeast of Willcox; through their cooperation the Geological Survey was allowed to conduct an aquifer test at the plant. 


\section{GEOGRAPHY}

\section{LOCATION AND EXTENT OF THE AREA}

The Willcox basin is in the northern part of the Sulphur Springs Valley, which is a large northwest-trending intermontane trough that extends from northeastern Sonora, Mexico, to the headwaters of Aravaipa Creek in Arizona. The basin is an area of interior drainage that is topographically and hydrologically separate from the Douglas basin, which is in the southern part of the Sulphur Springs Valley. The east side of the basin is bounded by the Pinaleno, Dos Cabezas, and Chiricahua Mountains; the west side, by the Galiuro, Winchester, Little Dragoon, and Dragoon Mountains. A short distance north of the southern drainage divide there is a series of low hills and buttes-Six Mile Hill, Pearce Hill, Turkey Creek Ridge, Sulphur Hills and Pat Hills. The basin is about 48 miles wide at its widest point, between the crests of the Little Dragoon and the Chiricahua Mountains; it is about 65 miles long from the northernmost point in the Pinaleno Mountains to the south end. The Willcox basin comprises about 1,500 square miles, of which the valley floor occupies about 950 square miles.

\section{CLIMATE}

The climate of the Willcox basin is characterized by hot summers and cool moderate winters. Convective-type thunderstorms produce intense rains of short duration from July to September. Frontal-type storms produce light general rains and snow in the winter. July and August have the greatest precipitation and April and May the least. The average annual pan evaporation at Willcox is 84.59 inches, which is more than seven times the average annual precipitation. Precipitation, temperature, and evaporation data from four stations in the Willcox basin are summarized in table 1 .

Although changes in water-level trends may correspond to periods of greater or lesser precipitation, the changes are probably not due to ground-water recharge from direct precipitation. Any change in water levels probably reflects the reduction or increase in groundwater withdrawal necessary for crop production during these periods. Figure 3 shows the accumulated deviation from the 1899-1957 average annual precipitation at Willcox. A rising trend denotes above-average precipitation, and a downward trend denotes below-average precipitation. For example, 1899-1904 was a dry period, and 1904-9 was a wet period. Four main periods of below-average precipitation, 1899-1904, 1909-13, 1921-25, and 1941-63, and three periods of above-average precipitation, 1904-9, 1913-21, and 1925-41, have occurred since the beginning of record at Willcox. 


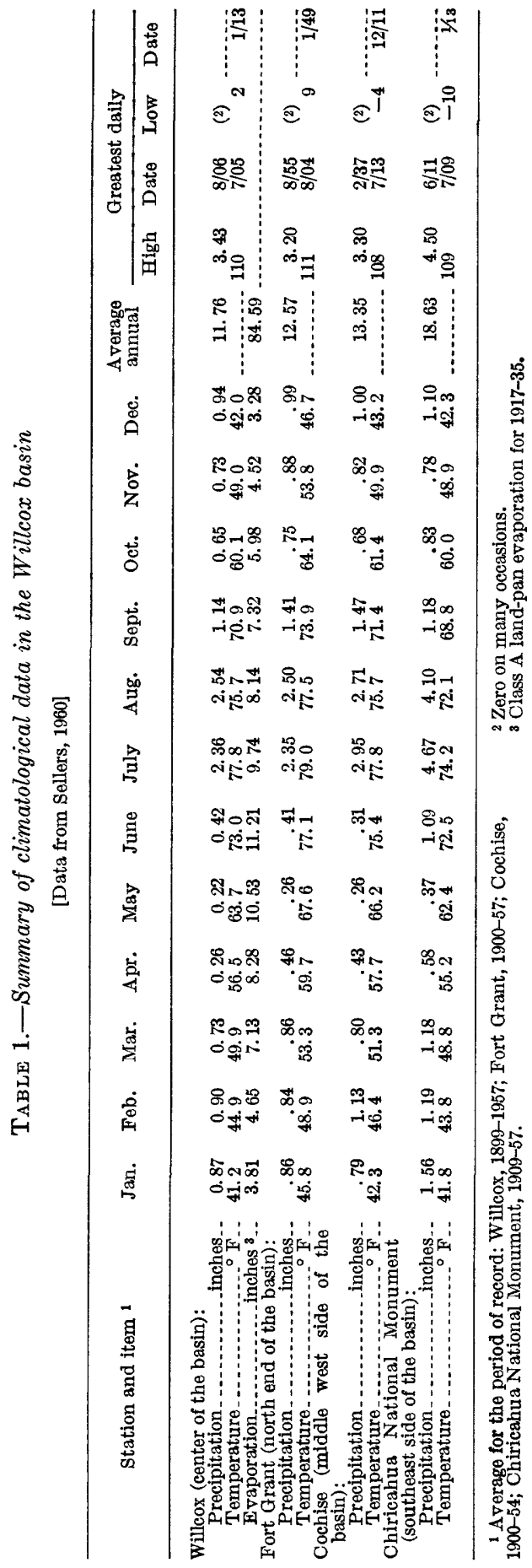




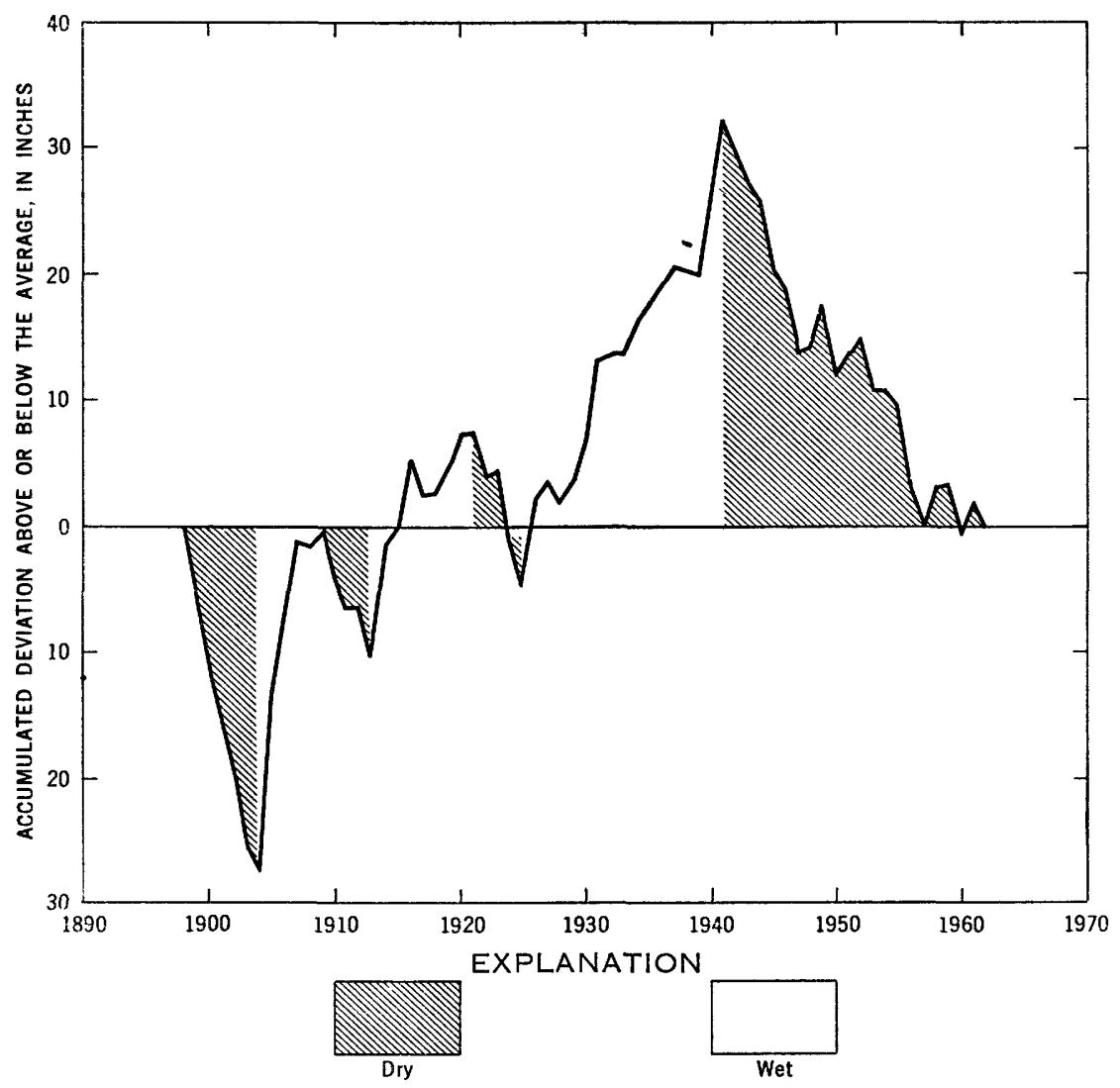

Figure 3.-Accumulated deviation from the 1899-1957 average annual precipitation at Willcox.

\section{TOPOGRAPHY AND DRAINAGE}

The Willcox basin is a northwest-trending valley that is bordered on the east and west by dissected mountain chains. The highest point along the east boundary of the basin is Mount Graham, which has an altitude of 10,713 feet above sea level. The highest point along the west boundary of the basin is Reiley Peak, which has an altitude of 7,631 feet.

Topographically, the northern part of the Sulphur Springs Valley is a closed basin that has interior drainage to the Willcox Playa, which occupies the lowest part of the valley. The Willcox basin is characterized by three major topographic features-the mountains, the stream-built slopes, and the playa flat. 
The mountains rise abruptly from beneath the alluvium that forms the valley floor. The mountain areas are composed of older rocks that have been uplifted, structurally deformed, and dissected by stream erosion, which has carved a rugged topography of great relief, steep slopes, and deep canyons.

The streams head in the mountains and spill out onto the gently sloping alluvial valley floor at about right angles to the mountain fronts. The streams deposit their sediment load on the alluvial slopes as the flow is attenuated by seepage and evaporation. The alluvial slopes are steepest near the mountains and become much flatter toward the central playa flat. Most of the streamflow that issues from the mountain fronts disappears before it reaches the central playa flat.

The axis of the Willcox basin is controlled by the widths of the valley slopes, which in turn are controlled by the size and height of the mountain ranges from which the slopes were derived (Meinzer and Kelton, 1913, p. 26). The mountain ranges on the east side of the basin are larger and higher than those on the west; thus, the eastern slopes of the valley are longer and gentler than the western slopes. As a result, the axis of the valley is generally closer to the west edge of the basin.

The Willcox Playa is a large, roughly "pork chop" shaped barren flat in the south-central part of the basin. The playa floor is a few feet below the surrounding surface because of the deflating action of the wind; it is bounded along its south edge by low beach ridges formed by the wave action of ancient Lake Cochise (Meinzer and Kelton, 1913, p. 34-35). A series of wind-built ridges and hills have formed along the northeast edge of the Willcox Playa southeast of Willcox.

\section{GEOLOGIC UNITS AND THEIR WATER-BEARING PROPERTIES}

The Willcox basin probably was formed during middle and late Tertiary time, when the area was subjected to large-scale normal faulting accompanied by the uplift of the mountain ranges that border the present basin (Sabins, 1957, p. 1339-1341). The rocks exposed in the mountains are igneous, metamorphic, and sedimentary, and they range in age from Precambrian through Tertiary.

During and after the faulting, which produced the present basin, large quantities of material were eroded from the adjacent mountains and were deposited in the downfaulted central part of the basin. The alluvial deposits consist of a coarse-grained facies, which was deposited by streams along the edges of the basin, and a fine-grained facies, which was deposited in one or more large lakes in the central part of the basin. 
The northern boundary of the Willcox basin has been displaced several miles to the south by the headward erosion of Aravaipa Creek. Streams continue to erode the mountain areas and to deposit sediment on the stream-built slopes that ring the central part of the basin. Sediment is presently being removed from the playa area by wind.

In this report the formations in the Willcox basin have been divided into two broad groups - the rocks of the mountain blocks and the rocks of the basin. The rocks of the mountain blocks generally yield only small quantities of water, but the rocks of the basin yield moderate to large quantities of water (pl. 1; table 2$)$.

\section{ROCKS OF THE MOUNTAIN BLOCKS}

The mountain blocks consist of igneous, metamorphic, and sedimentary rocks. The igneous rocks consist of granite, rhyolite, andesite, and small amounts of basalt and tuff. The metamorphic rocks are chiefly gneiss and schist. The sedimentary rocks consist of limestone, shale, sandstone, and quartzite.

The water-bearing characteristics of the rocks of the mountain blocks depend primarily on the degree of weathering and fracturing. Small water supplies for stock and domestic uses have been developed from wells drilled in fractured and jointed zones. Water has been encountered in mine shafts that were sunk into these rocks. In a few areas small springs issue from these rocks and provide sufficient water for stock water supplies (Jones and Cushman, 1947, p. 5-7).

\section{ROCKS OF THE BASIN}

\section{MODERATELY CONSOLIDATED AND POORIY CONSOLIDATED ALLUVIUM}

The moderately consolidated alluvium and the poorly consolidated alluvium crop out along the northern, southeastem, and western parts of the Willcox basin (pl.1). These units were differentiated in outcrop by the presence or absence of structural deformation.

The moderately consolidated alluvium has been deformed locally by tilting and by normal faulting, but not by thrust faulting. It is tilted as much as $29^{\circ}$ in the area northeast of the Circle I Hills. Secondary filling by carbonate material along fracture planes is common. The faulting and tilting indicate that this unit was deposited during or after the major structural events that formed the present basin. Although the poorly consolidated alluvium is lithologically similar to the moderately consolidated alluvium, it was not deformed as intensely where observed in outcrops; therefore, it probably was deposited after deformational activity had nearly ceased. 


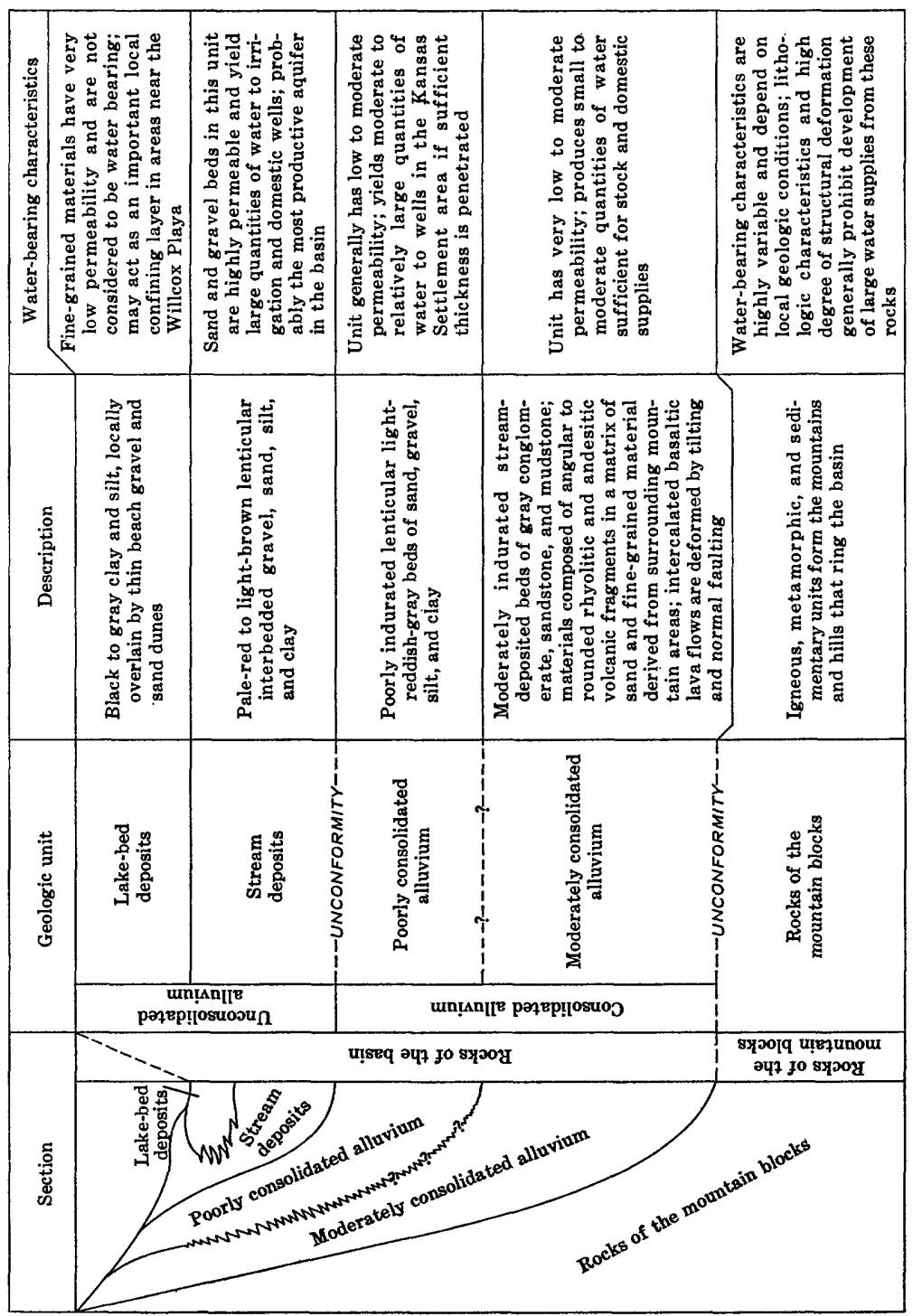


The moderately consolidated alluvium unconformably overlies the rocks of the mountain blocks and is overlain in most of the area by poorly consolidated alluvium and unconsolidated alluvium. The moderately consolidated alluvium consists of gray moderately indurated stream-deposited lenticular beds of gravel, sand, silt, and claysize material derived from the adjoining mountains. The coarsegrained fraction of these sediments consists almost entirely of rhyolitic and andesitic volcanic fragments in a matrix of sand and fine-grained material. Northeast of Willcox intercalated basaltic lava flows occur in this unit (Cooper, 1960).

The abundance of coarse-grained rhyolitic and andesitic volcanic fragments in this unit indicates that it was probably the first unit deposited in the present basin. The rhyolite and andesite represent the youngest rocks in the mountains; they were probably the first rocks to be removed by stream erosion and deposited in the central part of the basin as alluvium. The lithologic characteristics and the type of deformation of the moderately consolidated alluvium indicate it is similar to other units of Tertiary age in southern Arizona.

Because the poorly consolidated and the moderately consolidated alluvium have similar lithologic characteristics, these units are difficult to differentiate in drillers' logs, which constitute the bulk of the subsurface data; therefore, the units are undifferentiated in the geologic sections (pl. 1). The sections indicate that a fine-grained facies of the consolidated alluvium (moderately and poorly consolidated alluvium, undifferentiated) occurs in the north-central part of the basin.

The water-bearing characteristics of the consolidated alluvium. are not well known. Along the edges of the basin, however, wells that penetrate only the coarse-grained facies of the moderately consolidated alluvium usually produce small quantities of water for domestic and stock supplies. Fine-grained material and carbonate cement prevent the consolidated alluvium from readily yielding large quantities of water to wells.

Many wells in the Kansas Settlement area penetrate the consolidated alluvium after passing through the stream-deposit facies of the unconsolidated alluvium. Most of these wells produce water from both the consolidated and unconsolidated alluvium; therefore, the production from the consolidated alluvium alone cannot be readily determined from existing data. As the water table declines, the saturated thickness of the unconsolidated alluvium diminishes, and the well yields are reduced greatly; this reduction indicates that the consolidated alluvium is much less permeable than the overlying unconsolidated alluvium. An aquifer test performed on industrial well (D15-26) $23 \mathrm{dcc}$, which obtains all its water from the consolidated allu- 
vium, indicated a coefficient of transmissibility of about $6,000 \mathrm{gpd}$ (gallons per day) per foot for this unit at this point.

The consolidated alluvium probably yields little or no water to wells in the Stewart area, where it consists of moderately indurated finegrained material (pl.1).

\section{UNCONSOIIDATED ALIUVIUM}

The unconsolidated alluvium underlies most of the valley floor and consists of two facies-stream deposits and lake beds associated with the old playa. The stream deposits are exposed in about 55 percent of the basin, and the lake-bed deposits in about 9 percent of the basin. Where exposed, the unconsolidated alluvium unconformably overlies the older units and includes all deposits younger than the poorly consolidated alluvium. Along the present stream channels, the unconsolidated alluvium is overlain by channel deposits of Recent age, which in this report have been included with the stream deposits (pl. 1). The unconsolidated alluvium has been eroded only slightly in contrast with the older underlying formations and has not been deformed by faulting or tilting.

\section{STREAM DEPOSITS}

The stream deposits consist of interbedded lenses of gravel, sand, silt, and clay and mixtures of these materials. The deposits are pale red to light brown, exhibit fluviatile crossbedding, and are unconsolidated to weakly cemented by calcium carbonate or argillaceous material. The coarse-grained material in this unit consists of wellsorted to poorly sorted subrounded to angular sand and gravel composed of all the rock types exposed in the surrounding mountains. The composition of these deposits contrasts sharply with that of the consolidated alluvium, which is composed chiefly of volcanic rock fragments.

The stream deposits were laid down as alluvial fans by streams issuing from the adjacent mountains. The coarse-grained layers of the stream deposits are thin and highly lenticular. A well may penetrate a water-bearing sand or gravel strata at a given altitude, whereas a nearby well may penetrate only fine-grained material at the same altitude. It is not usually possible to correlate a thin sand or gravel bed from one well to another under these conditions.

The sand and gravel beds of the stream deposits constitute the most important aquifer in the Willcox basin. Although the bulk of the unit consists of impermeable silt and clay, the relatively thin sand and gravel stringers within the silt and clay are highly permeable.

$321-140-69-3$ 
Irrigation wells in the Stewart area obtain most of their water from the stream deposits. Wells in the Kansas Settlement area obtain water from both the unconsolidated alluvium and the underlying consolidated alluvium. The channel deposits that overlie the stream deposits locally contain perched water and supply a few domestic and stock wells near the mountains.

\section{LAKE-BED DEPOSITS}

Deposits associated with ancient Lake Cochise (Meinzer and Kelton, 1913 , p. 62-65) have been mapped in considerable detail by Cooper (1960). The lake-bed deposits crop out in the Willcox Playa and consist of uniform black to gray clay, which was deposited in a body of quiet water. Wave-worn beach gravel and wind-deposited sand dunes, which were associated with Lake Cochise, overlie the clay along the margins of the playa.

Meinzer and Kelton (1913, p. 62) drilled several shallow holes in the playa area and found only clay material. In 1960 the Geochronology Laboratories of the University of Arizona drilled a test hole 140 feet deep near the center of the playa; only black clay was penetrated. The U.S. Geological Survey drilled several auger holes along the east edge of the playa, and black clay was penetrated to depths of more than 50 feet. Black clay also is recognized in some drillers' logs.

Not all drillers, however, describe the material penetrated by wells in sufficient detail to permit the clay unit to be recognized; therefore, the subsurface distribution of black clay cannot be determined accurately from the existing data. The top of the clay unit is exposed at an altitude of about 4,136 feet in the playa area, but occurs at lower altitudes north of the playa.

Meinzer and Kelton (1913, p. 58) suggested that the differences in altitude of the top of the black clay unit may have been caused by erosion or by migration of the site of clay deposition to the south while stream deposition continued in the north end of the basin. The authors believe that the latter explanation is more likely.

The fine-grained lake-bed deposits act as a confining layer, which causes local artesian conditions near the Willcox Playa. Water under artesian pressure occurs in the thin layers of sand and gravel that are intercalated in the lake clay (Jones and Cushman, 1947, p. 8).

\section{GEOHYDROLOGY}

The Willcox basin is topographically and hydrologically a closed basin, and all the drainage is toward the Willcox Playa. Little or no ground water flows from the basin. Under predevelopment conditions, 
subsurface flow moved toward the Willcox Playa; there the subsurface flow and surface runoff were evaporated from the playa surface and were transpired by the vegetation in and around the playa.

\section{SURFACE WATER}

Surface-water runoff in the Willcox basin results from torrential summer thundershowers that are usually of short duration, from general winter rains that are usually of low intensity but of longer duration than the summer storms, and from snowmelt that comes from the mountains.

Records of streamflow into the Willcox basin have been obtained at only two gaging stations : Grant Creek near Fort Grant, drainage area of 12.5 square miles in the northern part of the basin, and at West Turkey Creek near Light, drainage area of about 19 square miles in the southern part of the basin (pl. 1). Records are available for Grant Creek gaging station only for August and September 1920; the records for West Turkey Creek gaging station extend from August 1919 through September 1925 (U.S. Geological Survey, 1954, p. 729-730). The average annual runoff at West Turkey Creek gaging station for the period of record was 5,500 acre-feet, or about 290 acre-feet per square mile per year.

\section{GROUND WATER}

The geology of the basin is the determining factor in the occurrence, distribution, and movement of ground water. Physical characteristics of the subsurface materials, such as porosity and degree of cementation, determine the ability of the materials to transmit and yield water.

\section{OCCURRENCE OF GROUND WATER}

The fundamental principles of ground-water occurrence have been discussed in detail by Meinzer (1923) and other investigators; therefore, only a brief discussion of these principles as they relate to groundwater conditions in the Willcox basin will be presented in this report.

The principal aquifer in the Willcox basin, the unconsolidated alluvium, consists of lenticular sand and gravel layers interbedded in siltand clay-size material. The other aquifers, which yield less water, consist of beds of poorly to moderately consolidated sand- and gravel-size material; these beds occur in the poorly consolidated alluvium and the moderately consolidated alluvium.

The lake-bed deposits of the unconsolidated alluvium are the confining layer which causes the local artesian conditions near the Willcox Playa. Flowing wells have been drilled only along the north and east sides of the playa. 
HYDRAUIIC PROPERTIES OF THE AQUTEER

In areas where ground water is to be used in large quantities, it is important to know the hydraulic properties of the aquifer. A determination of these properties makes it possible to understand the physics of the ground-water system and helps to evaluate the ground-water resources of an area in relation to its development. The hydraulic properties control the storage capacity, the total amount of water available for withdrawal, and the rate of transmission of water in the aquifer.

The specific capacity of a well-its yield in gallons per minute per foot of drawdown caused by pumping -is related to the water-bearing properties of the material from which the well obtains its water, but it also is affected by the manner in which the well is cased, perforated, and developed. Although the specific capacity of a well is only an approximate measure of the aquifer's ability to transmit water, an analysis of specific-capacity data indicates that the characteristics of the water-bearing units penetrated differ areally and with depth. In the main irrigated areas in the Willcox basin, an analysis of specific capacities of wells per 100 feet of saturated material penetrated indicates that the upper aquifer material is much more permeable than the deeper aquifer material.

In the Stewart area, most wells obtain water from the unconsolidated alluvium. The median specific capacity of the wells was $20 \mathrm{gpm}$ (gallons per minute) per foot of drawdown per 100 feet of saturated material penetrated. Values of specific capacity per 100 feet of saturated material penetrated were greater than $48 \mathrm{gpm}$ per foot for one-fourth of the wells and were less than $8.5 \mathrm{gpm}$ per foot for one-fourth of the wells (fig. 4 ). These values indicate a wide range in water-bearing properties of the materials underlying the area; the range between the upper 25 percent and the lower 25 percent of the wells is $39.5 \mathrm{gpm}$ per foot per 100 feet.

In the Kansas Settlement area, wells obtain water from the poorly consolidated and moderately consolidated alluvium, undifferentiated, and from the unconsolidated alluvium. The wells had a median specific capacity of $7.4 \mathrm{gpm}$ per foot of drawdown per 100 feet of saturated material penetrated. Values of specific capacity per 100 feet of saturated material penetrated were greater than $12 \mathrm{gpm}$ per foot for one-fourth of the wells and were less than $4.5 \mathrm{gpm}$ per foot for onefourth of the wells (fig. 4). The range between the upper 25 percent and the lower 25 percent of the wells was only $7.5 \mathrm{gpm}$ per foot per 100 feet. 


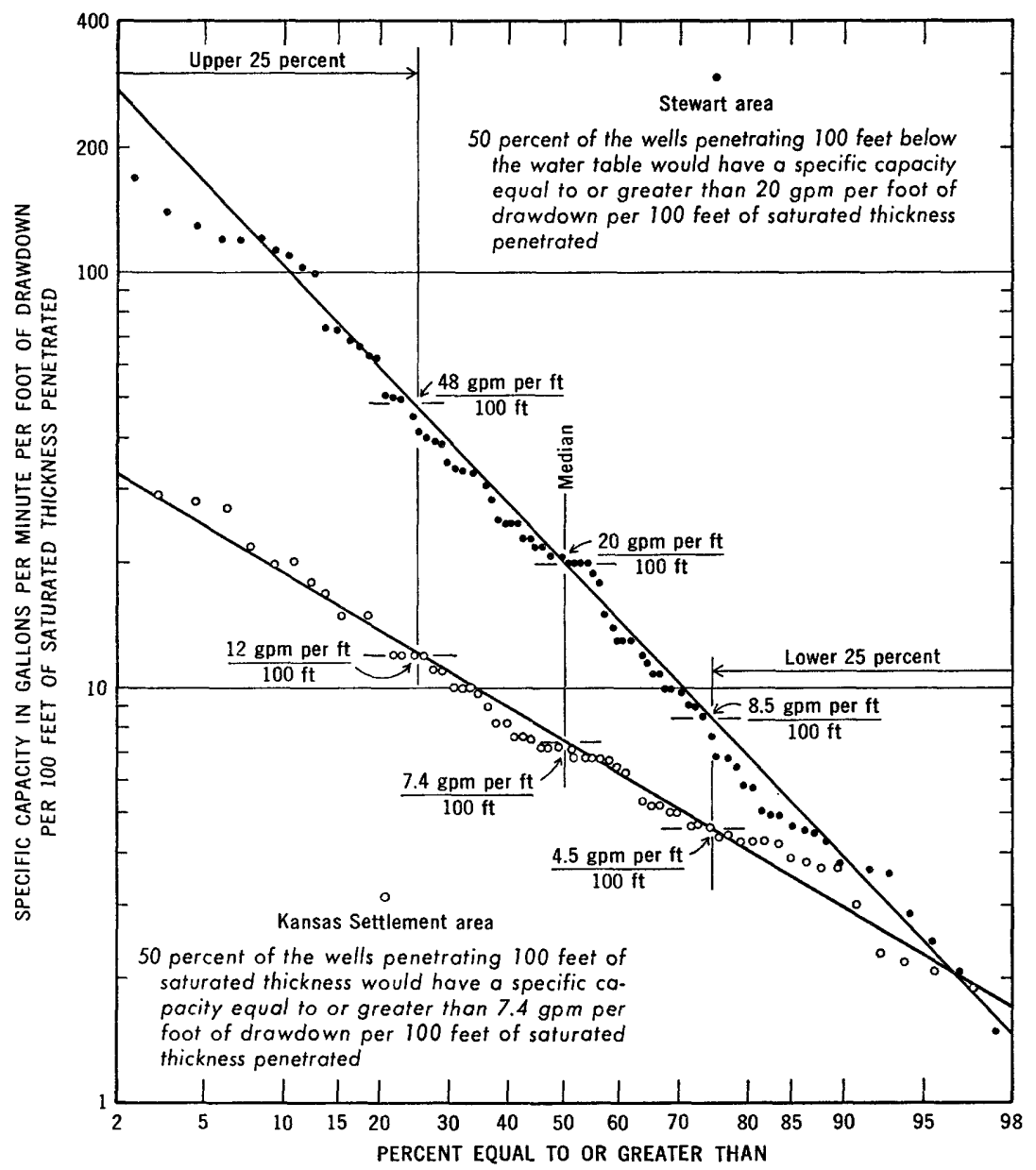

Frourn 4.-Specific capacities of wells in the Stewart and Kansas Settlement areas.

A comparison of the specific-capacity values for the two areas indicates that the aquifer materials penetrated in the Kansas Settlement area are much less permeable than those penetrated in the Stewart area. That the water-bearing characteristics of the aquifer materials vary less in the Kansas Settlement area than in the Stewart area indicates that the poorly consolidated and moderately consolidated alluvium are relatively homogeneous.

The coefficient of transmissibility of an aquifer is defined as the rate of flow of water, in gallons per day, at the prevailing water temperature, through a vertical strip of the aquifer 1 foot wide extending the 
full saturated thickness of the aquifer under a hydraulic gradient of 100 percent (Ferris and others, 1962). Coefficients of transmissibility of the aquifer materials in the basin were estimated from specificcapacity data using the method described by Thomasson, Olmsted, and LeRoux (1960, p. 220-223), in which the coefficient of transmissibility, $T$, is estimated from

where

$$
T=1,750 \frac{Q}{S_{w}}
$$

$Q=$ well discharge, in gallons per minute; and

$S_{w}=$ drawdown, in feet below static water level.

The coefficient of 1,750, used in this report, was determined by comparing aquifer-test data and specific capacities of wells in other areas of similar lithology. If only the highest specific capacities of wells and only wells of similar size, depth, and construction are used for an area, the effects of variation caused by well-entrance losses, well radius, and partial penetration of the aquifer can be minimized, and realistic estimates of the coefficient of transmissibility can be made.

The estimated average coefficient of transmissibility for four areas in the Willcox basin is listed below :

Location
Stewart area_astimated average
Noefficient of
ransmissibitity
$($ gpd

\section{SHAPE OF THE PIEZOMETRIC SURFACE AND DIRECTION OF GROUND-WATER MOVEMENT}

Prior to the development of ground water, the aquifer was in approximate hydrologic balance; movement of ground water was from areas of higher to areas of lower head in the aquifer, that is, from the zones of recharge to the zones of discharge. Depth to water was greatest near the mountain fronts around the edges of the basin and shallowest in the area of the playa.

The general shape of the piezometric surface-the altitude of the static water level in the aquifer (Meinzer, 1923, p. 38) -and the direction of movement of ground water prior to extensive ground-water pumpage in the Willcox basin are shown by the configuration of the piezometric contours (pl. 2). In 1910, when evaporation from the playa and transpiration by phreatophytes growing near the playa were the only means of ground-water discharge, the piezometric surface had 
the form of an elongated depression, and the surface sloped toward the playa from all directions. The surface sloped toward the playa along the west side of the basin at an average gradient of nearly 20 feet per mile, from the southeast side of the basin at an average gradient of about 10 feet per mile, and from the northwestern part of the basin at an average gradient of about 5 feet per mile.

By 1963, the large-scale removal of ground water had caused marked changes in the ground-water regimen of the Willcox basin. The depth to the static water level in wells had increased greatly in areas of largescale pumping, and the configuration of the piezometric surface had changed markedly. The withdrawal of ground water had caused the formation of two large cones of depression. One encompasses Willcox and most of the Stewart area; the other includes all the Kansas Settlement area and extends northward to a point about 5 miles east of Will$\operatorname{cox}(\mathrm{pl.2}$ ). A smaller cone of depression is north of Pearce southwest of the large cone of depression in the Kansas Settlement area.

The general direction of ground-water movement in 1963 was from the recharge areas along the mountain fronts toward the larger cones of depression and toward the playa (pl. 2). A comparison of the generalized flow lines for 1911 and 1963 shows the change in the direction of movement of ground water caused by large-scale pumping (pl. 2). The entire system has been altered, and in some areas the direction of flow has been reversed.

\section{ESTIMATES OF GROUND-WATER RECHARGE AND DISCHARGE}

The ground-water reservoir in the Willcox basin receives recharge from infiltration of streamflow along the mountain fronts. Little or no recharge is believed to result from direct precipitation on the valley floor. Some water may return to the ground-water reservoir from applied irrigation water; however, this does not constitute recharge but is only a recycling of a part of the water removed from the reservoir.

Prior to extensive development, ground water was discharged from the basin mainly by evaporation from the playa and transpiration by vegetation. The playa and the surrounding area of shallow ground water may be regarded as a huge evaporating dish where ground water and some of the surface runoff are lost to the atmosphere.

The evaporation rate from a water table 4 feet below the land surface in a tank containing fine-grained silt in the nearby Safford basin was about 1.3 feet per year (Jones and Cushman, 1947). The Willcox Playa covers about 33,000 acres, and the average depth to water in 1911 was about 5 feet (Meinzer and Kelton, 1913, pl. 2). Assuming an evaporation rate of 1 acre-foot per acre per year from the bare playa surface and assuming an average depth to water of 5 feet, about 33,000 
acre-feet of water per year was discharged as evaporation from the playa in 1911.

In this report, transpiration by mesquite was estimated from data presented by Meinzer and Kelton (1913), who mapped about 90,000 acres of low-growing mesquite in the central part of the northern Sulphur Springs Valley. Where depth to water is more than 25 feet, mesquite exists as a xerophyte, and it presents a poorly developed appearance that contrasts strongly with the lush, dense, well-developed growth that it usually attains if depth to water is less than 25 feet (Mower and others, 1964, p. 64). From pictures and descriptions by Meinzer and Kelton (1913), it is estimated that the areal density of mesquite near the playa, where depth to water ranged from 4 to 25 feet in 1911, was about 30 percent. Farther away from the playa, where depth to water was greater than 25 feet, it is estimated that the areal density was only 2 percent. Of the 90,000 acres of mesquite mapped, about 22,000 acres grew where depth to water was less than 25 feet. Jones and Cushman (1947) assumed that the mesquite used water at an average rate of 1 acre-foot per acre per year. Applying this use figure only to the area of 30 percent areal density, transpiration of ground water would be about 22,000 acre-feet per year.

The U.S. Department of Agriculture (1941) estimated that about 20,000 acre-feet of water was transpired annually by saltgrass near the playa. Use of water by saltgrass probably was about the same in 1911.

Discharge by evaporation and transpiration in the playa area in 1910-11 under relatively undeveloped conditions is estimated to have been about 75,000 acre-feet of water per year, as shown in the following tabulation:

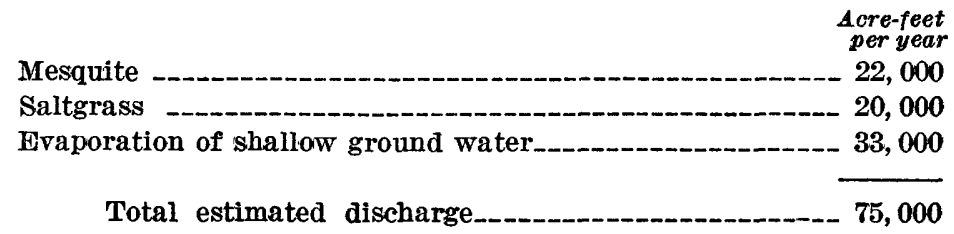

Assuming that the ground-water system was in equilibrium (recharge being equal to discharge) in 1910, the quantity of ground water discharged by evapotranspiration from and around the playa area would have been equal to the quantity of water recharged to the system at that time; thus, ground-water recharge would have been about 75,000 acre-feet per year in 1910. It must be recognized that there are many simplifying assumptions in the foregoing estimates of water use and that the value of recharge can only be considered an approximation. Ground water is probably being recharged at about the same rate today as it was in 1910. 
Recharge to the ground-water reservoir also was estimated by computing the quantity of water flowing through the aquifer to the discharge area, using the equation

in which

$$
Q=T I L
$$

$Q=$ underflow, in gallons per day;

$T=$ coefficient of transmissibility, in gallons per day per foot;

$I=$ hydraulic gradient, in feet per foot; and

$L=$ width, in feet, of cross section through which the flow takes place.

The gradient and the width of the section were determined from the 1910 piezometric-surface contours (pl. 2). The estimated coefficients of transmissibility for the subareas (p. F18) were used to compute the amount of underflow to the Willcox Playa area across the 4,170foot contour of the piezometric surface in 1910 (pl. 2). The computed amounts are:

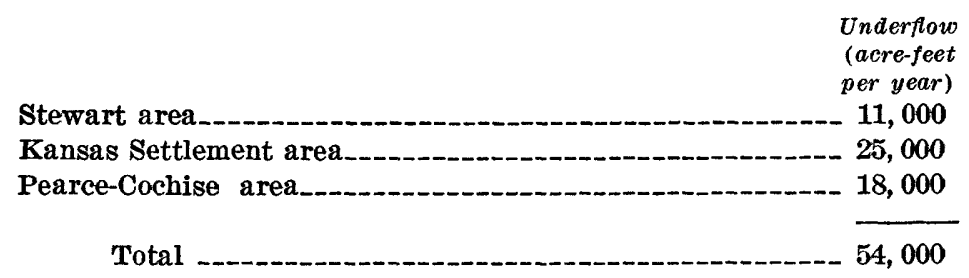

The coefficient of transmissibility used to compute underflow should represent the total thickness of the aquifers. The coefficients of transmissibility estimated from the specific-capacity data are conservative because the wells do not penetrate the total thickness of the aquifers. Thus, the 54,000 acre-feet of underflow calculated by this method is less than the actual underflow to the Willcox Playa area in 1910.

Values of calculated underflow and estimates of ground-water discharge by evaporation and transpiration from the playa area in 1910 indicate that ground-water recharge probably is between 54,000 and 75,000 acre-feet per year.

\section{EFFECTS OF GROUND-WATER DEVELOPMENT}

The ground-water system in an undeveloped basin is in approximate hydrologic equilibrium; that is, the long-term recharge equals the long-term discharge, although short-term recharge and discharge rates may be far out of balance. When wells are drilled and water is removed from the ground-water system, certain changes take place. 
As a well is pumped, the water level in the well is drawn down below the nonpumping level, water levels in the surrounding area are lowered, and ground water moves toward the pumped well. If several wells tap the same aquifer in an area, the drawdown caused by pumping one well adds to that caused by pumping another, and the resulting draw down in any of the wells is greater than it is if only a single well is pumped. Gradually the cones of depression expand enough that all discharging wells in an area affect one another. The result is a general lowering of the water levels in that area.

The water supplies in the Willcox basin are obtained principally from the ground-water reservoir, and most of the ground water pumped is withdrawn from storage. Recharge to the aquifers is small compared to the amount of water pumped each year. Underflow to the natural discharge area has decreased. In the Stewart and Kansas Settlement areas the direction of ground-water movement is toward the centers of pumping and away from the natural discharge area.

In 1963, water was discharged from the ground-water reservoir by pumping for irrigation, by evaporation from the playa surface, and by transpiration by vegetation. The amount of ground water discharged by evapotranspiration probably had been reduced by the removal of some phreatophytes during land clearing and also by the lowering of the water table, which resulted from pumping in areas adjacent to the playa. Pumping for irrigation was, by far, the greatest use of ground water in the basin in 1963.

\section{PUMPING OF GROUND WATER FOR IRRIGATION}

Some ground water has been used for irrigation in the Willcox basin since about 1910, but it was not until the mid-1940's that significant amounts were withdrawn. Meinzer and Kelton (1913) indicated that about 100 wells, excluding many wells equipped with windmills, were in use in 1910 in the Sulphur Springs Valley. How many of these wells were in the Willcox basin is not known, but Meinzer and Kelton indicated that the area northwest of Willcox was the most highly developed. The capacity of these wells ranged from 20 to $1,500 \mathrm{gpm}$; the average discharge was less than a few hundred gallons per minute. Quinton, Code, and Hill (engineers, Los Angeles, written commun., 1928) stated that in 1928 about 25 pumping plants supplied irrigation water for about 2,000 acres of land in the Stewart area. About 2 acre-feet of water per acre was applied for irrigation; thus, at that time about 4,000 acre-feet of water per year was withdrawn from the ground-water reservoir in the Stewart area. 
In 1945 , the first year for which pumpage was computed by the Geological Survey, the total amount of ground water pumped for irrigation was about 10,000 acre-feet; in 1963 about 180,000 acre-feet was pumped (fig. 5). For the irrigation seasons from 1945 to 1963 , some of the data shown in figure 5 have been revised and are different from that published in earlier reports. It is estimated that about $1,860,000$ acre-feet of water was pumped for irrigation in the Willcox basin through the 1963 irrigation season ; 680,000 acre-feet was pumped from the Stewart area, 990,000 acre-feet from the Kansas Settlement area, and 190,000 acre-feet from the Pearce-Cochise area. In the Sierra Bonita Ranch and north playa areas, the amount of ground water withdrawn through 1963 was negligible.

\section{SIERRA BONITA RANCF AREA}

The Sierra Bonita Ranch area is north of the Graham-Cochise County line and extends northward past Bonita to the ground-water divide at the headward end of Aravaipa Creek (pl. 2). In 1963 there was little irrigation in this area, and the small amount of ground water pumped was used for stock and domestic supplies.

\section{STEWART AREA}

The Stewart area is north of the Cascabel Road, north of U.S. Highway 666, and south of the Graham-Cochise County line (pl. 2). Irrigation with ground water in this area began as early as 1910. From 1945 through 1963 , irrigation pumpage increased from 8,000 to about 63,000 acre-feet per year (fig. 5).

\section{NORTH PLAYA AREA}

The north playa area is south of the Stewart area; on the west side of the playa it is bounded by the road that runs from Cochise to Johnson and on the north by State Highway 186 (pl. 2). Except north of State Highway 186 and northeast of the playa, almost no ground water is pumped for irrigation. No more than 1,000 acres was irrigated in this area in 1963; at the average rate of application of irrigation water in the Willcox basin, this indicates that about 3,000 acre-feet probably was pumped from this area in 1963. A considerable amount of ground water is also discharged by evaporation from the playa surface and by transpiration of shallow ground water by the saltgrass and scanty mesquite growing around the north borders of the playa. 


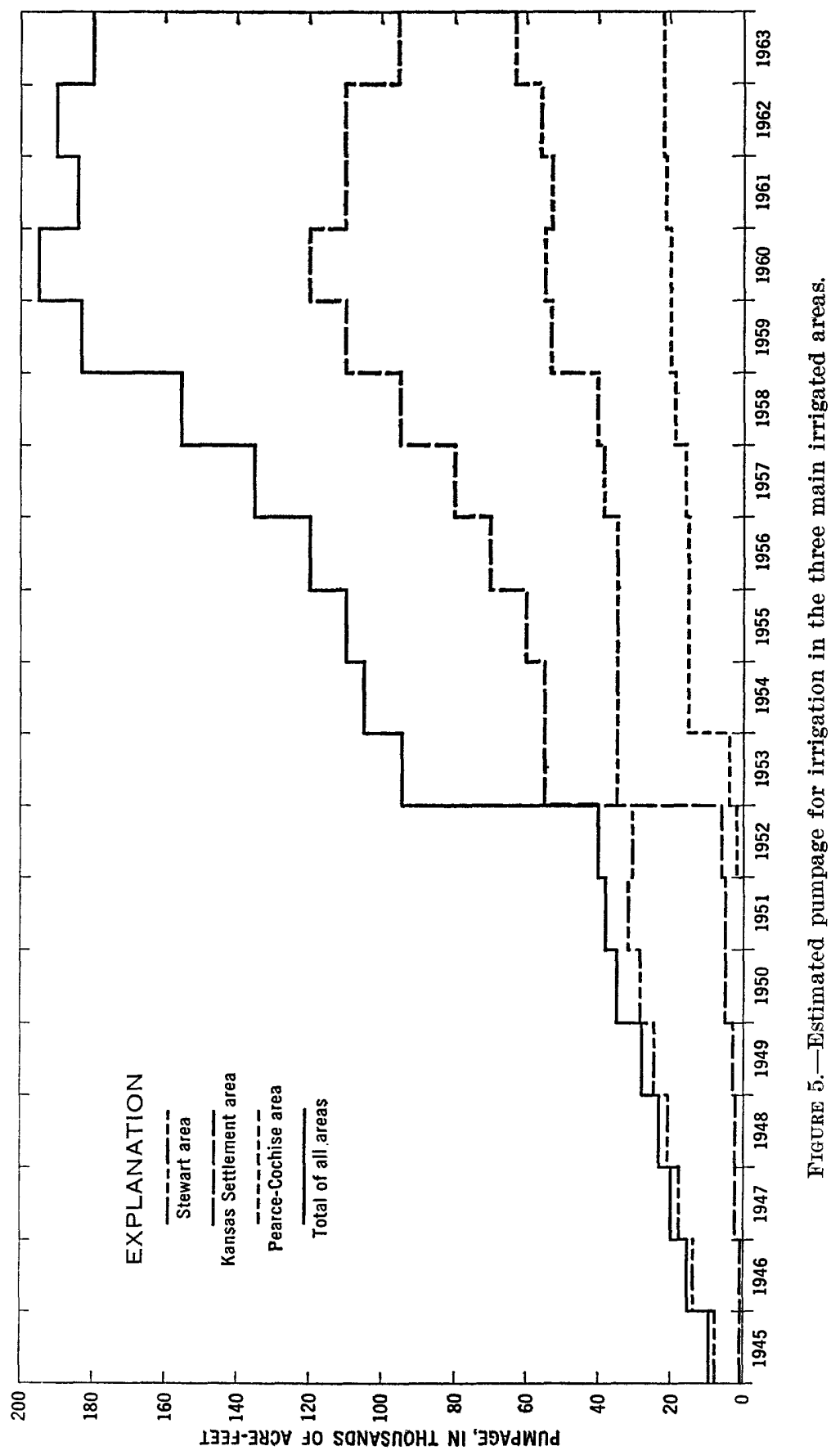


The Pearce-Cochise area is that part of the Willcox basin between the settlements of Pearce and Cochise and includes the area north of the topographic divide between the Douglas and Willcox basins (pl.2). Development of ground water for irrigation has not been as intense as in the Stewart or Kansas Settlement areas but has increased each year since 1952. In 1952 pumpage for irrigation was only slightly more than 1,000 acre-feet; by 1954 it had increased to 15,000 acre-feet; by 1963 it was 22,000 acre-feet (fig. 5). The total pumpage since 1945 is estimated to be 190,000 acre-feet, of which only 3,000 acre-feet was pumped prior to 1951. These amounts were calculated on the basis of estimated irrigated acreage (C. G. Page, County Agricultural Agent, written commun., 1964).

\section{RANSAS SETTLEMENT AREA}

The Kansas Settlement area is east of the playa, south of State Highway 186, west of State Highway 181, and north of the topographic divide that separates the Douglas and Willcox basins. Large-scale pumping for irrigation in the Kansas Settlement area began in 1953 (fig. 5). In the 1952 irrigation season the estimated pumpage was only 6,000 acre-feet, but by 1953 the pumpage had increased to more than 50,000 acre-feet. Maximum annual pumpage up to 1963 occurred in 1960, when 120,000 acre-feet was pumped; pumpage in 1963 was about 95,000 acre-feet.

\section{WATER-IEVEL CHANGES}

The amount of ground water being withdrawn annually in the Willcox basin greatly exceeds the amount of recharge, resulting in an overall decline of water levels in the basin. During the pumping season, the water levels in wells in the irrigated areas decline at a rapid rate; when the wells are shut down at the end of the pumping season, the water levels partly recover but do not attain the original static level. The rate and amount of decline in water levels is related to the amount of water withdrawn and the length of the pumping season.

\section{FLUCTUATIONS DUE TO CYCLIC PUMPING}

At the beginning of the irrigation season, the water levels decline at a rapid rate until the cone of depression expands sufficiently to bring water toward the well at a rate equal or nearly equal to the pumping rate. The water level then continues to decline at a slower rate until pumping is discontinued. In the irrigated areas, particularly in the Stewart, Kansas Settlement, and Pearce-Cochise areas, water levels are lowest at the peak of the irrigation season. At the end of the ir- 
rigation season when pumping stops, water levels begin to rise and continue to recover until pumping begins again. The hydrograph of water levels shown in figure 6 is taken from recorder charts and shows the drawdown and recovery of water levels during the irrigation season in well (D-13-24) 16bbb, an unused well in the Stewart area. The water level in the recorder well may reach the seasonal low as early as June or as late as the end of September. The high water level for the year has been recorded as early as January and as late as March, but most yearly highs occur in February. Depth to water in the recorder well is compared graphically with the cumulative pumpage in the Stewart area since 1945, the first year for which pumpage estimates were made (fig. 6). Since 1948, the seasonal water-
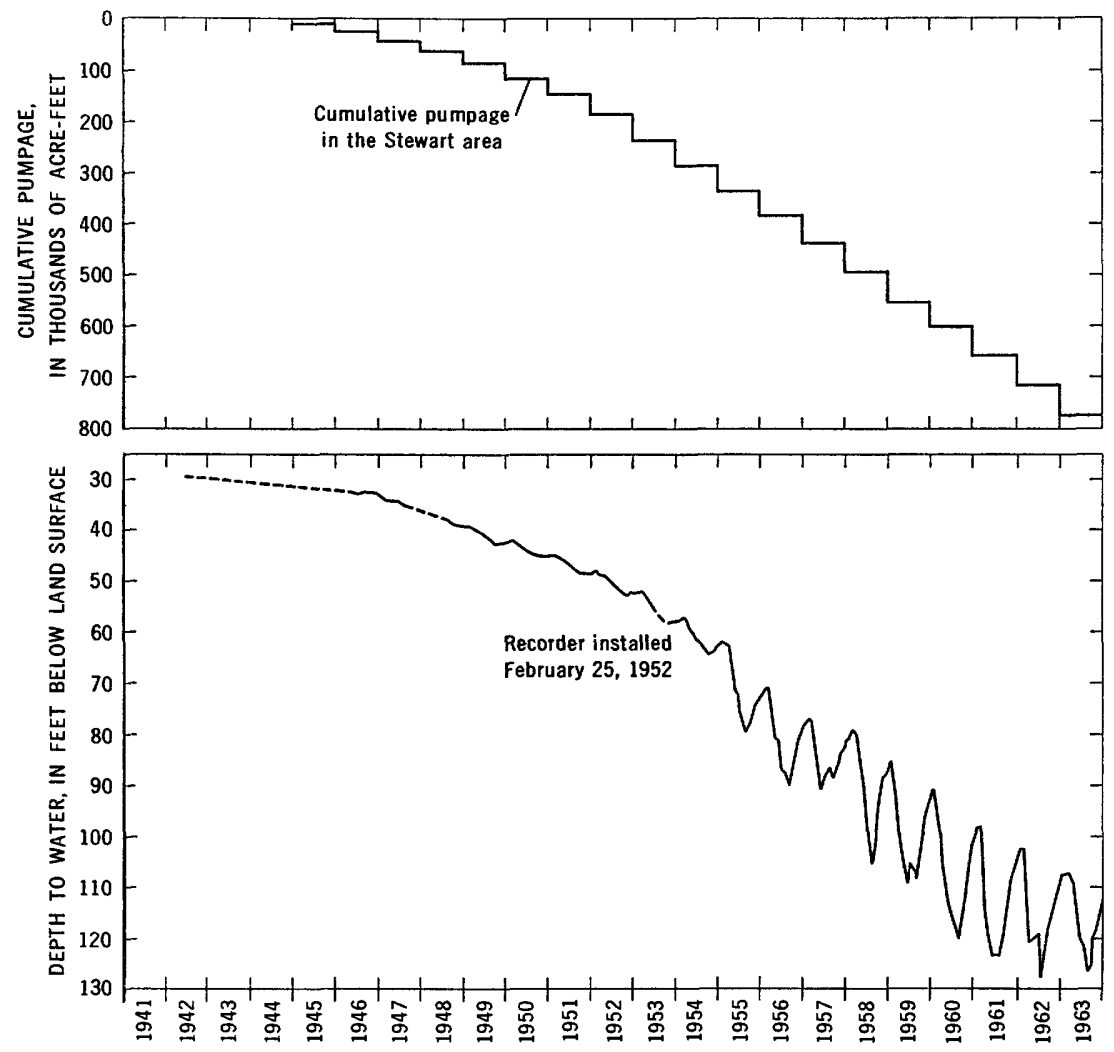

Frgure 6.-Cumulative pumpage in the Stewart area and water levels in well (D-13-24) 16bbb. Altitude is 4,209 feet; depth, 1,356 feet; highest monthly water level is graphed. 
level fluctuations caused by pumping have become progressively larger. In 1948, when the estimated pumpage in the Stewart area was about 14,000 acre-feet, the water level in the recorder well fluctuated only about 2 feet. As the amount of annual pumpage increased, the waterlevel fluctuations in the recorder well became greater. In 1960, the fluctuation was nearly 30 feet.

\section{CHANGES RELATED TO INCREASING GROUND-WATER WITHDRAWAL}

A ground-water system in an undeveloped basin, such as the Willcox basin was in 1910, is assumed to be in equilibrium - that is, the longterm recharge equals the long-term discharge by evaporation, transpiration, and all other sources. Meinzer and Kelton (1913), however, reported that water levels in two domestic wells near Willcox declined 7 feet in the 35 years prior to 1910 . These declines could be interpreted to indicate that discharge exceeded recharge and that the water table in the Willcox basin was adjusting itself to a lower level. It is more likely, however, that these reported declines were caused by development of cones of depression around the individual wells during 35 years of use.

Other evidence of water-level declines prior to large-scale pumping was reported by Quinton, Code, and Hill (engineers, Los Angeles, written commun., 1928). They compared the water levels measured in 15 wells by Meinzer and Kelton in 1910 with the water levels measured in the same wells in March 1922. The depth to water in these wells averaged 1.3 feet lower in 1922 than in 1910. In October 1926 , the depth to water was measured in 14 of the wells and averaged 2.0 feet lower than in March 1922 and 3.3 feet lower than in 1910.

Jones and Cushman (1947) reported that a comparison of the depth to water in 1910 with the depth to water in 1946 showed that water levels had declined in most of the basin and that near the playa the water level was from a fraction of a foot to as much as 5 feet below the water level measured in 1910. They also reported that the water level in a well 8 miles southwest of Willcox, in the NE1/4 NW1/4 sec 36, T. 14 S., R. 23 E., where there was no nearby pumping for irrigation, declined about 6 feet from 1910 to 1942,4 feet more from 1942 to 1946 , and 8.3 feet from 1946 to 1962 .

Changes in depth to water in the Willcox basin for 1910-52, a period of slow steady development, and 1953-63, a period of rapid development, are shown on plate 3 . Plate 3 shows that the largest declines from 1910 to 1952 occurred in the Stewart area, which was also the area of greatest development. After 1953, however, waterlevel declines in the Kansas Settlement area rapidly exceeded the declines in the Stewart area, because of the intensive development 
that began about that time and the less permeable character of the aquifer in that area (pl.3).

Cumulative changes in water levels in 16 observation wells having continuous records from 1952 have been compared with the average cumulative changes in water levels for all observation wells in individual areas in the Willcox basin (fig. 7). The effects of heavy pumping in a given area can extend some distance away; for example, pumping in the Stewart area has caused declines of water levels northward into the Sierra Bonita Ranch area and southward into the north playa area.

The trend of the water levels in each of the five areas-Sierra Bonita Ranch, Stewart, north playa, Pearce-Cochise, and Kansas Settlement areas-is downward. In the areas where there are small to moderate amounts of irrigation, the rates of water-level decline are much Jess than in the intensely irrigated Stewart and Kansas Settlement areas; the greatest declines occur in the Kansas Settlement area. Additional development anywhere in the Willcox basin can only increase the rates of decline of water levels in immediate and nearby areas.

STERRA BONITA RANCH AREA

From 1952 to 1963 the cumulative average annual water-level declines had reached about 14 feet in the Sierra Bonita Ranch area. The cumulative-change curve for well (D-10-22)20abc showed a slight rise from 1952 to 1963 (fig. 7) ; but this well was dug in an area of shallow ground water near an ephemeral stream, and water levels in the well reflect the recharge from this stream. Stock wells (D-10-23) 35acb and (D-11-23) 15add, in which water levels have declined regularly since 1955 , are in an area where only small amounts of water were pumped for stock use through 1963. By spring 1963, the heavy pumping for irrigation in the Stewart area to the south had caused the 20-foot decline zone to extend to a point about 2 miles north of the GrahamCochise County line (pl. 3). Thus, although there has been little pumping of ground water for irrigation in the Sierra Bonita Ranch area, water levels have declined since 1952 because of the heavy draft in the Stewart area south of the Graham-Cochise County line. Any additional pumping will cause the rate of water-level decline to increase in both the Sierra Bonita Ranch area and the Stewart area.

STEWART AREA

Ground-water levels have declined steadily since 1910 in this area. The cumulative-change graphs (fig. 7) show declines ranging from 10 to more than 60 feet since 1952. The cumulative average annual 

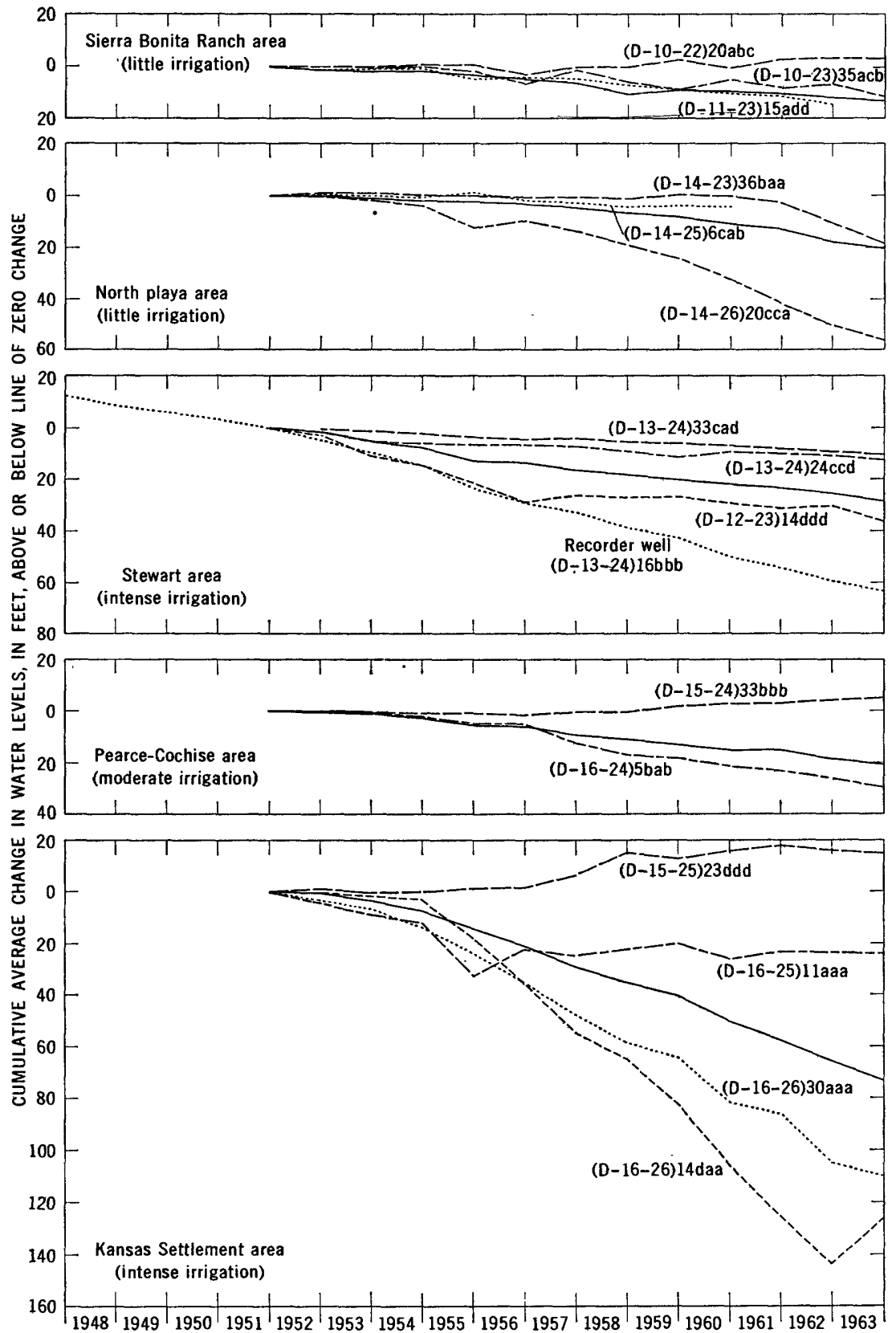

Figure 7.-Oumulative change in water levels in observation wells. Solid line represents cumulative average annual declines in all wells in each area. 
change since 1952 for all wells of record in the Stewart area shows an average annual decline of nearly 30 feet. The water level in well (D13-24) $16 \mathrm{bbb}$ has declined continuously since 1948 and has declined about 62 feet since 1952 because of pumping for irrigation (fig. 7).

\section{NORTH PLAYA AREA}

The trend of water levels since 1952 has been generally downward in this area (fig. 7). From 1952 through 1963, the cumulative average decline in all observation wells exceeded 20 feet. The water level in well (D-14-26) 20cca in the lightly irrigated eastern part of the area has declined about 55 feet since 1952; in well (D-14-23) 36baa in the nonirrigated area north of Cochise the water level rose slightly prior to early 1955 but has declined since that time to about 19 feet below the 1952 level, with the major part of the decline occurring in 1962 and 1963. The rapid decline probably was caused by the expansion of the cone of depression in the heavily pumped Stewart area and, to some extent, by the expanding cones of depression in the Kansas Settlement and Pearce-Cochise areas.

PEARCE-COCHISE AREA

The average water-level decline in all wells measured in this area has been almost 20 feet since 1952 (fig. 7). Between 1952 and 1963, however, the water level in well (D-15-24)33bbb declined slightly and then rose to almost 5 feet above its 1952 level. The water level in well (D-16-24)5bab has declined steadily to 30 feet below its 1952 level.

\section{KANSAS SETTLEMENT AREA}

The average water-level decline in the Kansas Settlement area was less than 1 foot from January 1952 to February 1953, but from 1953 to 1954 the average water-level decline was almost 4 feet below the 1952 level (fig. 7). In 1963 the average decline in all observation wells since 1952 was 80 feet. By spring 1963 the water level in well (D-1626) $14 \mathrm{daa}$, near the area of maximum decline, had dropped more than 140 feet. The water level in well (D-15-25) 23ddd, about 3 miles from the playa, has risen about 14 feet since 1952, and water levels in other wells in this area have risen steadily since that time. Artesian wells of low head were noted by Meinzer and Kelton (1913) and Jones and Cushman (1947) in this area. The water-level rises may be explained in two ways. First, wells drilled in this area commonly are perforated from static water level to the bottom of the casing; the perforations allow the deeper water that may be at higher head to circulate upward 
in the well casing and into the shallower aquifers. Second, the waterlevel rises may be caused by infiltration of excess tailwater from irrigated fields; the tailwater runs off onto the sandy surface soil nearer the playa and percolates into the ground-water reservoir.

RELATION OF PUMPage AND WATER-LEVEL CHANGES

The following tabulation summarizes the pumpage and the average, maximum, and minimum water-level changes for the three main irrigated areas:

\begin{tabular}{|c|c|c|c|c|}
\hline \multirow{2}{*}{ Area } & \multirow{2}{*}{$\begin{array}{l}\text { Total pumpage } \\
\text { from spring } 1968 \\
\text { to spring } 1964 \\
\text { (acre-ft) }\end{array}$} & \multicolumn{3}{|c|}{$\begin{array}{c}\text { Changes in water level from spring } 1952 \\
\text { to spring } 1964(\mathrm{ft})\end{array}$} \\
\hline & & $\begin{array}{l}\text { Average of } \\
\text { all wells }\end{array}$ & Maximum & Minimum \\
\hline $\begin{array}{l}\text { Stewart } \\
\text { Pearce-Cochise } \\
\text { Kansas Settlement }\end{array}$ & $\begin{array}{l}531,000 \\
190,000 \\
966,000\end{array}$ & $\begin{array}{l}-29 \\
-19 \\
-74\end{array}$ & $\begin{array}{r}-64 \\
-30 \\
-127\end{array}$ & $\begin{array}{r}-11 \\
+5 \\
+14\end{array}$ \\
\hline
\end{tabular}

\section{CONCLUSIONS}

Recharge to the Willcox basin under natural prepumping conditions is estimated to have been from about 54,000 to 75,000 acre-feet per year. In 1963 the pumpage from the irrigated areas was estimated to be 180,000 acre-feet. The total pumpage for irrigation in $1963 \mathrm{ex}-$ ceeded natural recharge by about 105,000 to as much as 126,000 acrefeet. Water-level declines exceeded 10 feet per year in some wells in the heavily pumped Kansas Settlement area and 7 feet per year in the Stewart area for 1962-63. As the cones of depression around individual wells expanded and coalesced, the slope of the piezometric surface around the irrigated areas steepened, and water moved toward the areas of pumping and away from the areas of natural discharge. The rate of recharge did not increase because there was no rejected recharge, and consequently, water levels in the recharge areas declined. A large part of the ground water now being pumped in the Willcox basin is being mined from storage. Increased pumping for irrigation in areas that are now only slightly developed will accelerate the rates of decline of the water levels in these areas. 


\section{REFERENCES CITED}

Brown, S. G., Schumann, H. H., Kister, L. R., and Johnson, P. W., 1963, Basic ground-water data of the Willcox basin, Graham and Cochise Counties, Arizona: Arizona State Land Dept. Water-Resources Rept. 14, 93 p.

Cooper, J. R., 1959, Reconnaissance geologic map of southeastern Cochise County, Arizona: U.S. Geol. Survey Mineral Inv. Field Studies Map MF-213.

1960, Reconnaissance map of the Willcox, Fisher Hills, Cochise, and Dos Cabezas quadrangles, Cochise and Graham Counties, Arizona: U.S. Geol. Survey Mineral Inv. Field Studies Map MF-231.

Creasey, S. C., Jackson, E. D., and Gulbrandsen, R. A., 1961, Reconnaissance geologic map of parts of the San Pedro and Aravaipa Valleys, south-central Arizona: U.S. Geol. Survey Mineral Inv. Field Studies Map MF-238.

Ferris, J. G., Knowles, D. B., Brown, R. H., and Stallman, R. W., 1962, Theory of aquifer tests: U.S. Geol. Survey Water-Supply Paper 1536-E, p. 69-174.

Gilluly, James, 1956, General geology of central Cochise County, Arizona, with sections on Age and correlation by A. R. Palmer, J. S. Williams, and J. B. Reeside, Jr.: U.S. Geol. Survey Prof. Paper 281, 169 p.

Jones, R. S., and Cushman, R. L., 1947, Geology and ground-water resources of the Willcox basin, Cochise and Graham Counties, Arizona, with a section on Quality of water by J. D. Hem: U.S. Geol. Survey open-file report, 35 p.

Kister, L. R., Brown, S. G., Schumann, H. H., and Johnson, P. W., 1966, Maps showing fluoride content and salinity of ground water in the Willcox basin, Graham and Cochise Counties, Arizona : U.S. Geol. Survey Hydrol. Inv. Atlas HA-214.

Meinzer, O. E., 1923, Outline of ground-water hydrology, with definitions: U.S. Geol. Survey Water-Supply Paper 494, 71 p.

Meinzer, O. E., and Kelton, F. C., 1913, Geology and water resources of Sulphur Spring Valley, Arizona, with a section on Agriculture by R. H. Forbes: U.S. Geol. Survey Water-Supply Paper 320, 231 p.

Mower, R. W., Hood, J. W., Cushman, R. L., Borton, R. L., and Galloway, S. E., 1964, An appraisal of potential ground-water salvage along the Pecos River between Acme and Artesia, New Mexico: U.S. Geol. Survey Water-Supply Paper 1659, $98 \mathrm{p}$.

Sabins, F. F., Jr., 1957, Geology of the Cochise Head and western part of the Vanar quadrangles, Arizona: Geol. Soc. America Bull., v. 68, no. 10, p. $1315-1341$.

Sellers, W. D., ed., 1960, Arizona climate : Tucson, Univ. Arizona Press, 60 p.

Thomasson, H. G., Jr., Olmstead, F. H., and LeRoux, E. F., 1960, Geology, water resources, and usable ground-water storage capacity of part of Solano County, California : U.S. Geol. Survey Water-Supply Paper 1464, 693 p.

U.S. Department of Agriculture, 1941, Water facilities area plan for northern Sulphur Springs Valley area, Arizona: Bur. Agr. Econ., 89 p.

U.S. Geological Survey, 1954, Compilation of records of surface waters of the United States through September 1950, pt. 9, Colorado River basin: U.S. Geol. Survey Water-Supply Paper 1313, 749 p.

Wilson, E. D., and others, 1958, Geologic map of Graham and Greenlee Counties, Arizona : Arizona Bur. Mines. 